\title{
APPLICATION OF NANOSCALE POLYMER COLLOID CARRIERS FOR TARGETED DELIVERY OF THE BRAIN-DERIVED NEUROTROPHIC FACTOR THROUGH THE BLOOD-BRAIN BARRIER IN EXPERIMENTAL PARKINSONISM
}

Kapitonova MYu' ${ }^{1}$, Alyautdin RN²区, Wan-Syazli RWAL ${ }^{3}$, Nor-Ashikin MNK ${ }^{3}$, Ahmad A ${ }^{3}$, Norita S ${ }^{3}$, Dydykin SS ${ }^{4}$

${ }^{1}$ Faculty of Medicine and Health Sciences, University Malaysia Sarawak (UNIMAS), Kota Samarahan, Sarawak, Malaysia

2 Department for Expertise of Medicinal Products safety, Scientific Centre for Expert Evaluation of Medicinal Products, Moscow

${ }^{3}$ Faculty of Medicine, University Teknologi MARA, Sungai Buloh, Selangor, Malaysia

Lepartment of Operative Surgery and Topographic Anatomy, Sechenov First Moscow State Medical University, Moscow

Parkinson disease is one of the common age-related motor neurodegenerative diseases, in which dopamine neurons degeneration is considered to be pathognomic for the development of motor disfunction. Brain-derived neurotrophic factor (BDNF) is a member of the neurotrophin family, which is considered to be a key regulator of neuronal plasticity. BDNF, being a large molecule, does not pass through the blood-brain barrier (BBB). Synthetic polymer nanoparticles (NP), covered by surfactant, provide the phenomenon of "Trojan hoarse" and enable BDNF to penetrate into the brain tissue. For modelling of parkinsonism we used an intraperitoneal (i.p.) injection of neurotoxin 1-methyl-4-phenyl-1,2,3,6-tetrahydropyridine (MPTP) which was injected to the C57BL/6 mice with subsequest treatment with normal saline (group 1), BDNF (group 2), nanoparticulate BDNF (group 3) and surfactant-coated nanoparticulate BDNF (group 4). After $90 \mathrm{~min}, 24$ hours, 72 hours and 7 days manifestations of parkinsonism were evaluated using behavioural tests of open field, rota-rod, assessment of the tremor, length of the body and pace. At the end of experiment the brain was sampled for histological evaluation of changes in the striatum and midbrain and concentration of BDNF in the brain tissues. The results of the experiments demonstrated that nanoparticulate BDNF covered with surfactant significanltly reduced rigidity of the skeletal muscles, oligokinesia and tremor, and also significantly increased BDNF concentration in the brain tissues.

Keywords: brain-derived neurotrophic factor, parkinsonism, nanoparticles, blood-brain barrier, ELISA

Funding: this work was supported by the grant 600-RMI/RAGS 5/3 (92/2013) of the Universiti Teknologi MARA (UiTM), Selangor, Malaysia.

$\triangle$ Correspondence should be addressed: Renad N. Alayutdin

1 Volokolamskiy Proezd 10, bl. 4, Moscow, 119876; alyautdun@mail.ru

Received: 09.07.18 Accepted: 20.08.18

DOI: $10.24075 /$ brsmu.2018.072

\section{ПРИМЕНЕНИЕ ПОЛИМЕРНЫХ КОЛЛОИДНЫХ НОСИТЕЛЕЙ ДЛЯ ТАРГЕТНОЙ ДОСТАВКИ МОЗГОВОГО ТРОФИЧЕСКОГО ФАКТОРА ЧЕРЕЗ ГЕМАТО- ЭНЦЕФАЛИЧЕСКИЙ БАРЬЕР ПРИ ЭКСПЕРИМЕНТАЛЬНОМ ПАРКИНСОНИЗМЕ}

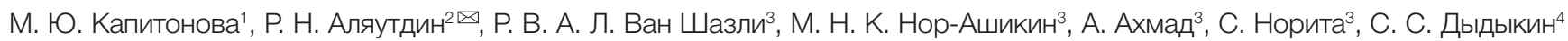

' Факультет медицины и здравоохранения, Университет Малайзии Саравак (ЮНИМАС), Кота-Самарахан, Саравак, Малайзия

2 Управление экспертизы безопасности лекарственных средств, Научный центр экспертизы средств медицинского применения, Москва

${ }^{3}$ Медицинский факультет, Университет технологии МАРА, Сунгай Було, Селангор, Малайзия

${ }^{4}$ Кафедра оперативной хирургии и топографической анатомии, Сеченовский Первый Московский государственный медицинский университет, Москва

Болезнь Паркинсона - одно из распространенных возрастных моторных нейродегенеративных заболеваний, при котором дегенерация дофаминергических нейронов считается патогномоничной для развития моторной диссункции. Мозговой трофический фактор (БДНФ) считается ключевым регулятором нейронной пластичности и, являясь крупной молекулой, не проходит через гемато-энцесалический барьер (ГЭБ). Синтетические полимерные наночастицы (НЧ), покрытые сурфактантом, обеспечивают феномен «троянского коня» и позволяют доставлять БДНФ в ткани головного мозга. Целью работы было оценить нейропротективное действие БДНФ, сорбированного на полилактидных НЧ, в общепринятой модели паркинсонизма, вызванного применением МФТП. Для моделирования синдрома паркинсонизма использовали нейротоксин 1-метил-4-фенил-1,2,3,6-тетрагидропиридин (МФТП), который внутрибрюшинно вводили мышам линии C57BL/6 с последующим внутривенным введением физраствора (1-я группа мышей), раствора БДНФ (2-я группа), БДНФ, сорбированного на полилактидных НЧ (3-я группа), и БДНФ, сорбированного на полилактидных НЧ, покрытых сурфактантом (4-я группа). Через 90 мин, 24 ч, 72 ч и 7 суток оценивали проявления паркинсонизма в поведенческих тестах открытого поля, на рота-роде, по интенсивности тремора, изменению длины тела и шага животных. По окончании эксперимента головной мозг извлекали для гистологической оценки изменений в стриапаллидарной системе и среднем мозге, а также для определения концентрации БДНФ в тканях головного мозга. Результаты показали, что БДНФ, сорбированный на полилактидных НЧ, покрытых сурфактаном, существенно уменьшал ригидность скелетных мышц, олигокинезию и тремор, а также достоверно повышал концентрацию БДНФ в тканях головного мозга.

Ключевые слова: мозговой трофический фактор, паркинсонизм, наночастицы, гемато-энцефалический барьер, иммуносерментый анализ

Финансирование: исследование выполнено в рамках гранта 600-RMI/RAGS 5/3 (92/2013) Университета технологии МАРA, Селангор, Малайзия.

Для корреспонденции: Ренад Николаевич Аляутдин

1-й Волоколамский проезд, д. 10, корп. 4, г. Москва, 119876; e-mail: alyautdun@mail.ru

Статья получена: 09.07.18 Статья принята к печати: 20.08.18

DOI: 10.24075/vrgmu.2018.072 
The main trend of modern pharmacology is to increase efficacy of the medications with decrease of their toxicity and side effects. Analysis of modern literature revealed two main ways to solve this problem: firstly, to increase selective action of the drugs, and secondly, to provide higher concentration of the medications at the targeted structures, particularly in the central nervous system (CNS) at the expense of directed transport of the drugs using specific carriers [1, 2]. Trying to implement the first direction, we are facing certain limitations, such as presence of the targets with equal sensitivity in different structures of the body which makes the desired selectivity not feasible; persuing the second direction, we come across another limitation, such as toxicity of the carriers for the distant delivery of the drugs, while high selectivity becomes a considerable advantage in this case. Besides, certain potentially important medications were recently identified, such as tumor necrosis factor, which requires both distant and selective delivery to the target organs. Presence of the BBB is an essential obstacle for penetration of many medications into the brain. Tight junctions between the endothelial cells of the brain capillaries interfere with penetration of many high molecular weight and hydrophilic substances into the brain tissues, while presence of the P-glycoprotein hampers penetration of certain lipophilic molecules into the brain $[3,4]$. Thus, presence of the $\mathrm{BBB}$ is a major limitation for the medicinal correction of the neurodegenerative diseases, tumors and other pathologies of the CNS.

Many peptides and proteins are known as regulators of different functions of the CNS neurons and therefore may potentially be used for treatment of different conditions accompanied by neurodegeneration [5, 6]. Important limitation for clinical application of the peptide medications is their low capacity in penetration through the BBB and their liability to enzymatic inactivation. Polymer colloid systems are capable of providing transport of the medications, including proteins and peptides, into the brain [7].

For modelling of parkinsonism MPTP is a common compound which penetrates through the BBB and forms a metabolite in the brain which blocks thyrosine-hydroxylase, which finally results in deficiency of dopamine in substantia nigra [8]. In our research for the purpose of assessment of BDNF delivery and achievement of the neuroprotective effect in modelled parkinsonism we applied biodegradable surfactantcoated polylactate NP.

The objective of this study is to evaluate neuroprotective effect of nanoparticulate BDNF sorbed on to the polylactic NP in the established model of parkinsonism caused by MPTP.

\section{METHODS}

Experiments were conducted using the C57BL/6 male mice weighing 20-25 g (Animal house "LACU", Institute of the Medical Molecular Biotechnology (IMMB), Universiti Teknologi MARA, Selangor; Malaysia). All animals were given one week to adjust to the laboratory conditions before the experiment started. Each mouse was used only once in the experiment. The animals were having free access to food and water, kept in the temperature of $20-22{ }^{\circ} \mathrm{C}$ and humidity $50-60 \%$, with a 12/12 dark/light cycle in the standard steel cages with 4 mice per cage. To minimise circadian fluctuations and avoid chronopharmacological effects, all experiments were conducted starting from 9 o'clock in the morning. Each experimental group contained 6-8 animals.

Parkinsonism was modelled using neurotoxin MPTP injected i. p. [9]. Evaluation of the major extrapyramidal changes were conducted starting from the of MPTP injection continuously for $45 \mathrm{~min}$ as described below; thereafter the animals were divided into 4 groups and got an injection into the lateral tail vein of $0.2 \mathrm{ml}$ of one of the medications: $1^{\text {st }}$ group - normal saline, $2^{\text {nd }}$ group - BDNF, $3^{\text {rd }}$ group - nanoparticulate BDNF, $4^{\text {th }}$ group - surfactant-coated (poloxamer 188) nanoparticulate BDNF. All behavioural tests and observations were conducted 90 min, 24 hours, 72 hours and 7 days after injection of neurotoxin.

After the last test was completed on the $8^{\text {th }}$ day of experiment, all the animals were euthanized by decapitation. Brain was sampled, with the right hemisphere fixed in the $10 \%$ formalin for subsequent histological examination, while the left hemisphere was frozen by liquid nitrogen in $-70^{\circ}$ with subsequent determination of level of BDNF in the brain using ELISA.

\section{Chemicals}

For parkinsonism modelling we used officinal normal saline (0.9\% sodium chloride) (Sigma Aldrich; USA); 1-Methyl-4phenyl-1,2,3,6-tetra hydropyridine hydrochloride powder (Sigma-Aldrich; USA).

For treatment of parkinsonism the following chemicals were used: officinal normal saline (0.9\% sodium chloride) (SigmaAldrich; USA); 10\% solution of poloxamer 188 (Sigma-Aldrich; USA), recombinant human BDNF (Raybiotech; USA); polylactic NP of medium diameter $200 \mathrm{~nm}$ (Degradex TM PLGA (MW 45-75 KD) nanospheres) (Phosphorex, Inc.; USA).

For ELISA we used a set of chemicals for ELISA of BDNF in mice and rats (Total BDNF Immunoassay; Quantikine ${ }^{\oplus}$ ELISA, Catalog Number DBNTOO) (R\&D Systems, Inc; USA), phosphate buffer (Sigma-Aldrich; USA) and lysis buffer 17 (catalog \#895943; R\&D system, Abingdon; UK,).

\section{Modelling of parkinsonism}

Solution of MPTP was injected i.p. to all animals in a dose of $30 \mathrm{mg} / \mathrm{kg}$.

\section{Preparation of nanoparticulate BDNF}

Lyophilized powder of BDNF (50 mkg) was dissolved in $1 \mathrm{ml}$ of normal saline. Solution of BDNF was added to the suspension of NP (40 mg in $1 \mathrm{ml}$ of normal saline) and incubated at low temperature $\left(0-4^{\circ} \mathrm{C}\right)$ for 3 hours with subsequent sonification in the ultrasound disintegrator for $15 \mathrm{~min}$ at the power $60 \mathrm{w}$ and stirred by magnetic stirrer at the speed of 300 RPM for 3 hours.

\section{Preparation of the suspension of NP}

Lyophilised powder (40 mg) of NP, containing $23.53 \mathrm{mg}$ of polymer, was dispersed in $1 \mathrm{ml}$ of the normal saline until a homogeneous suspension of the lacteous white color is obtained. Sonification was conducted in the ultrasound disintegrator for 15 min with power of $60 \mathrm{w}$ with subsequent stirring by magnetic stirrer at the speed of 300 RPM for 3 hours.

\section{Preparation of the suspension of NP with BDNF and surfactant}

Suspension of nanoparticulate BDNF was added to $0.2 \mathrm{ml}$ of $10 \%$ poloxamer 188 with subsequest stirring by magnetic stirrer. The final $2 \mathrm{ml}$ of preparation contained $1.18 \%$ suspension of NP covered by poloxamer and $50 \mathrm{mcg}$ of BDNF ( $5 \mathrm{mcg}$ of BDNF per $0.2 \mathrm{ml}$ of the preparation). In this case we used only 
$0.9 \mathrm{ml}$ of normal saline to dissolve NP and BDNF to maintain total volume of $2 \mathrm{ml}$ of the preparation.

Total of $0.2 \mathrm{ml}$ of normal saline or pure BDNF or nanoparticulate BDNF or nanoparticulate BDNF with poloxamer were injected intravenously (i.v.) to the animals of the $1^{\text {st }}, 2^{\text {nd }}, 3^{\text {rd }}$ and $4^{\text {th }}$ groups respectively into the lateral tail vein 45 min after the injection of the MPTP.

Efficacy of the preparations was evaluated by its capacity to attenuate the main manifestations of parkinsonism caused by MPTP (oligokinesia, rigidity and tremor). We also considered presence and intensity of such symptoms as salivation, piloerection, retropulsion and respiratory failure.

\section{Methods for evaluation of rigidity}

For quantitative evaluation of rigidity we used a symptom of humpback, the extent of which depends on muscular rigidity and may be measured by the shortening of the distance from the tail to the base of the tail. Body length was measured from interauricular line to the base of the tail using videoimages in the open field test. Paws of the animal were marked with a special dye using two different colors for front and rear limbs. Pace was measured between the footprints left by the moving animals on the tape. Rota-rod test was conducted in the RotaRod ENV-576 (Med Associates; USA) in accelerated mode N5 (2-20 RPM).

\section{Evaluation of tremor}

Tremor was assessed by its intensity in grades and by the number of animals with tremor per group. Based on localization and range, tremor was evaluated as grade 0 - no tremor, grade 1 - low range local tremor of the head, front paws and tail, grade 2 - local middle range tremor, grade 3 generalized low or middle range tremor of the whole body [10].

\section{Open field test}

Parkinsonism induced by neurotoxin causes changes not only of quantity of locomotor activity, but of its quality as well. The term "oligokinesia" refers to reduction of the volume of movements and change of their qualitative features. Open field is a white tetragonal arena with white borders $50 \mathrm{~cm}$ high. Its space is divided into 64 equal quadrates $10 \times 10 \mathrm{~cm}$ each. After each testing the bottom of the arena was wiped with a humid sponge.

For testing in the open field, the animal was placed into the center of arena for 3 minutes immediately after MPTP injection and then 90 min, 24 hours, 72 hours and 7 days after neurotoxin injection. For assessment of the horizontal activity, one crossed quadrate was taken as a unit of distance. Vertical activity included rearing of the animal with the front paws hanging or leaning against the borders of the arena. Both types of locomotor activity were considered as rearing.

\section{ELISA}

The following equipment was used for ELISA: microplate reader Victor $^{\mathrm{TM}} X$ to measure absorbance at $450 \mathrm{~nm}$ (Perkin Elmer; USA), tissue homogenizer Omni-Ruptor 4000 (OMNI International Inc.; US), horizontal orbital shaker with speed of 500+/-50 rpm (VISION Scientific Co. Ltd; Korea).

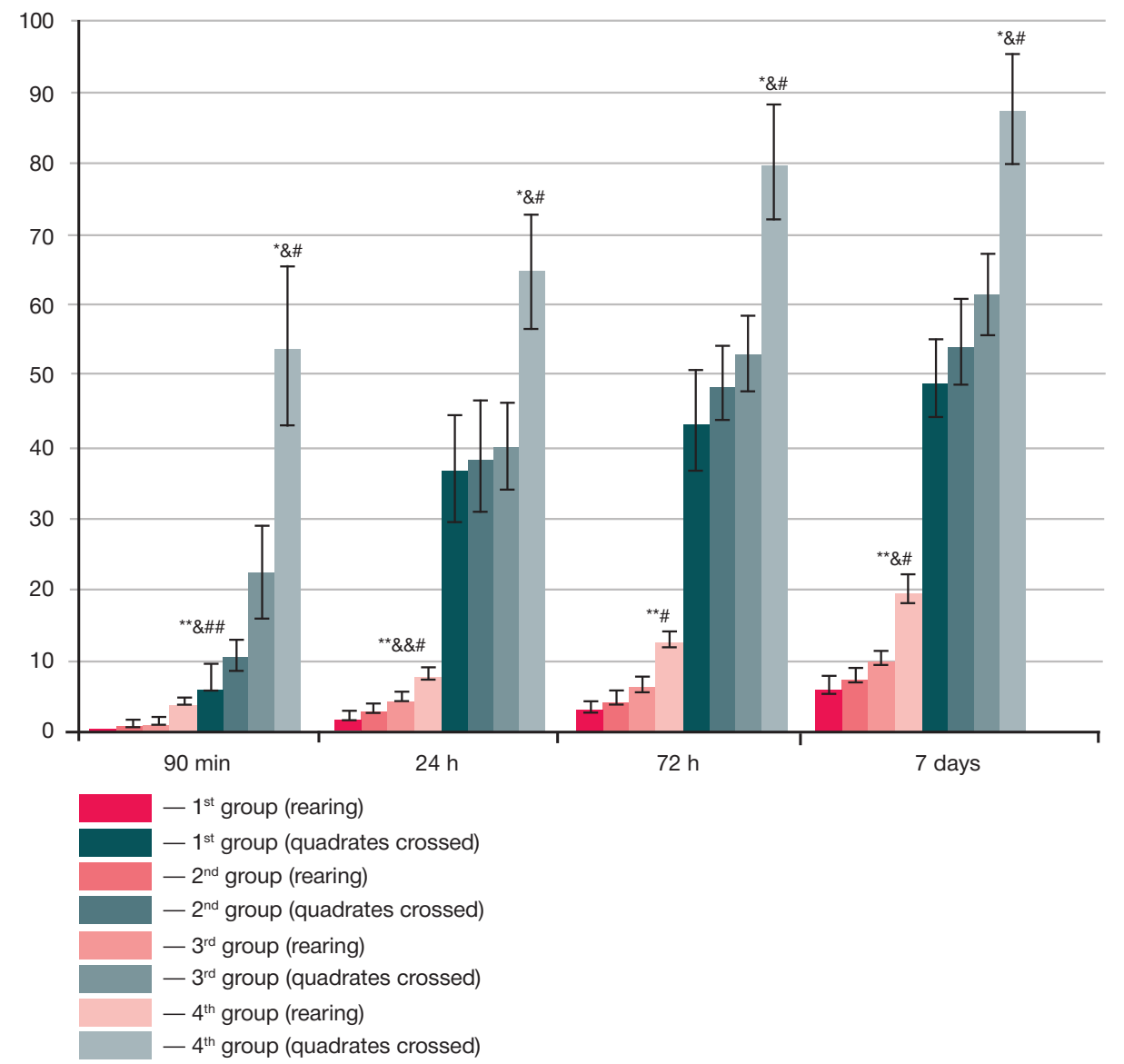

Fig. 1. Open field test results in experimental and control mice with modelled parkinsonism $(\mathrm{m} \pm \mathrm{SEM}) .{ }^{*}-p<0.05$ compared to the $1^{\text {st }}$ group, ${ }^{* *}-p<0.01$ compared to the $1^{\text {st }}$ group, $\&-p<0.05$ compared to the $2^{\text {nd }}$ group, \&\& $-p<0.01$ compared to the $2^{\text {nd }}$ group, $\#-p<0.05$ compared to the $3^{\text {rd }}$ group, \#\# $-p<0.01$ compared to the $3^{\text {rd }}$ group 
Left hemisphere of the brain was rinsed with phosphate buffer and homogenized with a tissue homogenizer in $500 \mu$ of PBS. An equal volume of lysis buffer 17 (R\&D Systems, Abingdon, UK) was added and tissues were lysed at room temperature for 30 minutes with gentle agitation. Debris was then removed by centrifugation at $10,000 \mathrm{~g}, 4^{\circ} \mathrm{C}$, aliquoted and stored at $-80^{\circ} \mathrm{C}$ before analysis. BDNF level was assesses using ELISA kit (Total BDNF Immunoassay; Quantikine ${ }^{\circledR}$ ELISA) (R\&D Systems, Inc.; USA) according to the manufacturer protocol using microplate reader Victor ${ }^{\mathrm{TM}} \mathrm{X}$ (Perkin Elmer; USA) with

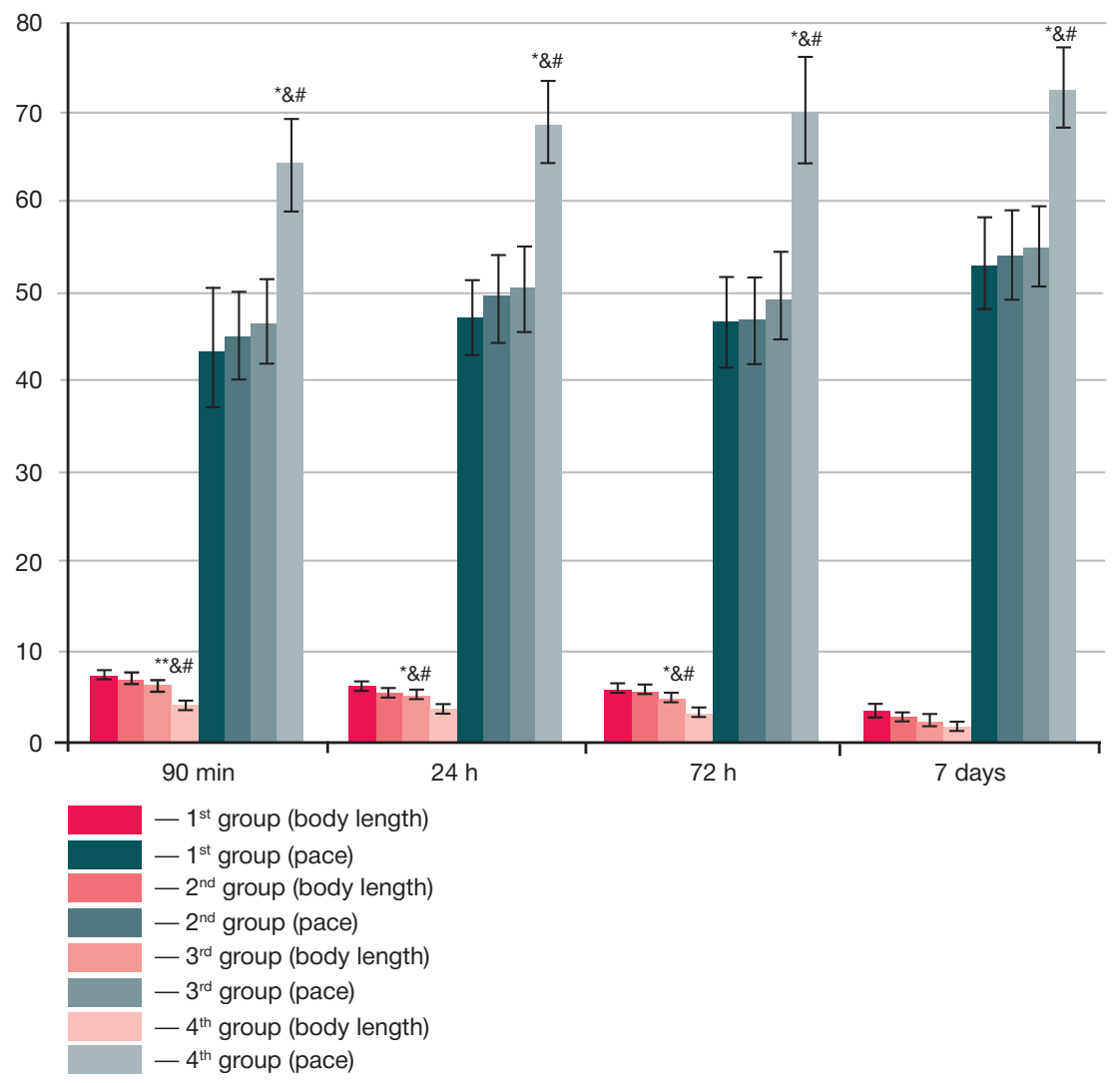

Fig. 2. Body length and pace in the experimental and control mice with modelled parkinsonism, $\mathrm{mm}(\mathrm{m} \pm \mathrm{SEM})$. ${ }^{*}-p<0.05$ compared to the $1^{\text {st }}$ group, ${ }^{* *}-p<0.01$ compared to the $1^{\text {st }}$ group, $\&-p<0.05$ compared to the $2^{\text {nd }}$ group, \&\& $-p<0.01$ compared to the $2^{\text {nd }}$ group, \# $-p<0.05$ compared to the $3^{\text {rd }}$ group, \#\# $-p<0.01$ compared to the $3^{\text {rd }}$ group

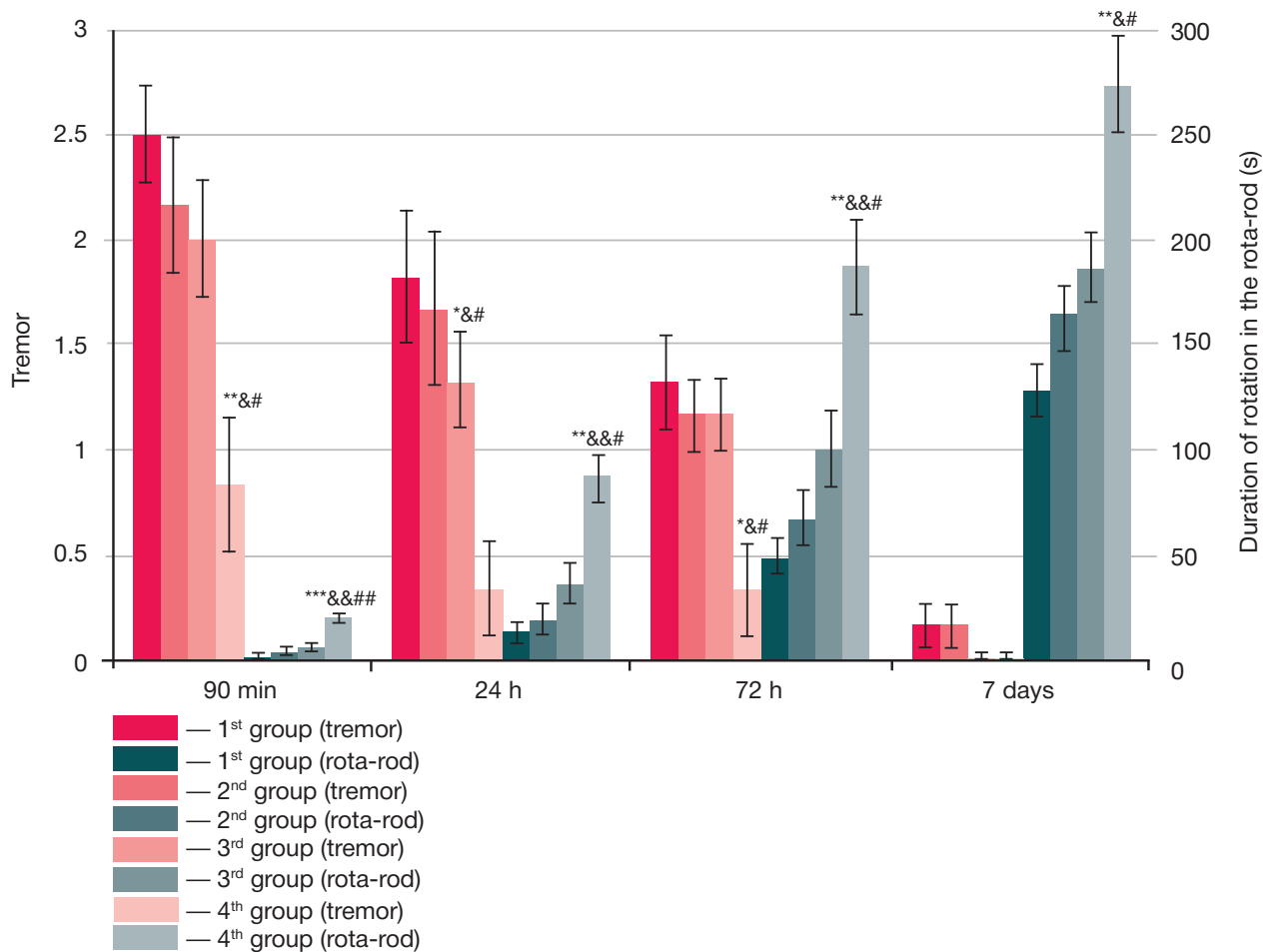

Fig. 3. Tremor and duration of rotation in rota-rod (sec) in experimental and control mice with modelled parkinsonism (m \pm SEM). ${ }^{*}-p<0.05$ compared to the $1^{\text {st }}$ group, ${ }^{* *}-p<0.01$ compared to the $1^{\text {st }}$ group, $\&-p<0.05$ compared to the $2^{\text {nd }}$ group, $\& \&-p<0.01$ compared to the $2^{\text {nd }}$ group, \# $-p<0.05$ compared to the $3^{\text {rd }}$ group, \#\# - $p<0.01$ compared to the $3^{\text {rd }}$ group 
Table 1. Concentration of BDNF in the brain tissue of mice with modelled parkinsonism after treatment with normal saline and BDNF preparations, pg/mg ( $\mathrm{m}+/-\mathrm{SE}$ )

\begin{tabular}{|c|c|c|c|}
\hline $1^{\text {st }}$ group & $2^{\text {nd }}$ group & $3^{\text {rd }}$ group & $4^{\text {th }}$ group \\
\hline $163.91 \pm 10.17$ & $184.03 \pm 2.28$ & $194.51 \pm 1.14^{\star} \# \#$ & $204.46 \pm 3.71^{\star \star} \# \# \&$ \\
\hline
\end{tabular}

Note: * $-p<0.05$ compared to normal saline; ${ }^{*}-p<0.01$ compared to normal saline; \#\# $-p<0.01$ compared to BDNF; \& $-p<0.05$ compared to nanoparticulate BDNF.

$450 \mathrm{~nm}$ wavelength. The optical density reading of sample at $450 \mathrm{~nm}$ wavelength was subtracted with $570 \mathrm{~nm}$ wavelength to avoid imperfection plate. The results of the ELISA as expressed as $\mathrm{pg} / \mathrm{mg}$ of total protein.

\section{Statistics}

The data obtained were processed statistically using Excel software with calculation of the mean, standard deviation, mean error, Student's t-test. Difference were considered significant if $p<0.05$.

\section{RESULTS}

As early as 2 minutes past i.p. injection of MPTP the animals of all four groups developed symptoms of parkinsonism: at first generalized tremor, low or middle range, then within the next 3-5 min - retropulsion and piloerection. Piloerection was so prominent, that in many mice white skin was visible between the hair of the black coat, which was especially pronounced at the back of the neck. During next 15 min the symptoms of skeletal muscles rigidity are dominating, namely staggering gait, shortened pace, rotational movements, shortening of the body with appearance of a typical humpback in the thoraco-lumbar region of the vertebral column. After 1.5 hours (45 minutes past injection of BDNF or saline) in mice of the $1^{\text {st }}$ group tremor persisted, rearings were absent, while in groups 2 and 3 tremor was slightly reduced and single rearings might be observed, and in the $4^{\text {th }}$ group tremor almost disappeared and rearings became much more frequent. Animals of the $4^{\text {th }}$ group showed ability to restore the pace and rota-rod rotation, as well as to increase the distance walked in the open field. In animals of the $1^{\text {st }}-3^{\text {rd }}$ groups rota-rod test results and the pace almost did not change, while distance walked and body length did not change only in the $1^{\text {st }}$ and $2^{\text {nd }}$ groups, but demonstrated a trend to increase in the $3^{\text {rd }}$ group of mice. Statistical analysis showed that only mice of the $4^{\text {th }}$ group revealed positive dynamics for all the listed parameters compared to all other groups, while in groups 1, 2 and 3 they did not differ significantly (Fig. 1-3).

After 24 and 72 hours since the start of the experiment the trends observed after 90 minutes for distance walked, pace, body length, rota-rod rotation and tremor, persist, though with different level of significance $(p<0.05-p<0.01)$. After 7 days mice of the $3^{\text {rd }}$ and $4^{\text {th }}$ groups did not show any tremor, while in the $1^{\text {st }}$ and $2^{\text {nd }}$ groups single twitching took place in some animals, but there was no significant difference for this parameter due to considerable variations between the species. Body length continues to restore in all the groups, but the difference between the groups is also not significant. Pace, rota-rod performance, distance walked and rearing remained significantly different in the $4^{\text {th }}$ group compared to all other groups.

As follows from the table 1, injection of BDNF insignificantly (by $11 \%$ ) increased concentration of BDNF in brain compared to the normal saline $(p>0.05)$, while nanoparticulate BDNF increased it significantly $(p<0.05)$ and surfactant-coated nanoparticulate increased with higher significance $(p<0.01)$ compared to normal saline group. Concentration of BDNF in the brain tissues in animals treated with nanoparticulate BDNF and surfactant-coated nanopaticulate BDNF was significantly higher $(p<0.01)$ than with pure BDNF. Animals treated with nanoparticulate BDNF and nanoparticulate BDNF with surfactant also showed significant difference in BDNF concentration in the brain tissues $(p<0.05)$.

\section{DISCUSSION}

Our experiments demonstrated that i.v. injection of poloxamercoated nanoparticulate BDNF loaded onto PLGA NP significantly increases concentration of neurotrophin in the brain. As a result, BDNF delivered to the brain tissues provides considerable alleviation of the symptoms of MPTP-induced parkinsonism. I. v. injection of pure BDNF did not show any significant antiparkinsonic effect. Significant reduction of rigidity and normalization of locomotor activity was detected only in the group of mice with parkinsonism treated by nanoparticulate BDNF with poloxamer. This effect was observed starting from the 45 minutes after BDNF injection continuously for 7 days. Similar effect on MPTP-related tremor was demonstrated in the group of mice after application of nanoparticulate BDNF with poloxamer. Observed trend of increased BDNF concentration after i. v. injection of pure neurotrophin allows to assume the presence of a transporting system in cells forming BBB. The data obtained correlate with the results regarding directed transport using colloid NP. Experiments with polybutirate NP covered by polysorbate 80 demonstrated that nerve growth factor (NGF) may be delivered into the brain. NGF was shown to be able to reduce intensity of symptoms caused by MPTP in mice $[9,10]$.

Currently activating effect of BDNF on regeneration of the nerve tissue is under thorough investigation. Thus, Limongi et al. demonstrated that incubation of the nerve tissue in the medium containing BDNF will increase density of the synaptic contacts and neuronal survival rate [11]. Besides, BDNF increases release of acetylcholine and glutamate by the synaptic structures of the central and peripheral nervous system [12, 13]. These mediators form the key mechanisms in functioning of the extrapyramidal system and development of parkinsonism. As it was shown by Bhurtel et al., BDNF stimulates dopaminergic neurons [14]. At the same time direct injection of the BDNF into brain reduced the intensity of symptoms of parkinsonism caused by injection of MPTP [15].

Thus we presume that BDNF delivered to the brain with the aid of NP may decrease intensity of symptoms of parkinsonism caused by MPTP due to direct stimulation of discharge of the mediators and/or stimulation of the regeneratory capacity of the dopaminergic neurons.

\section{CONCLUSIONS}

The results obtained demonstrated that poloxamer 188-coated polylactic NP are capable of transporting of the BDNF through the $\mathrm{BBB}$, thus creating its concentration in the brain which is able to cause significant neurotropic effect in the brain. 


\section{References}

1. Alyautdin RN, Deshmukh R, Petrov VE. Transport lekarstvennykh veshchestv cherez gematoencephalicheskiy barier. Vestnik NII Molekulyarnoy meditsiny. 2003; 11-29.

2. Lockman PR, Mumper RJ, Khan MA, Allen DD. Nanoparticle technology for drug delivery across blood-brain barrier. Drug Dev Ind Pharm. 2002; 28 (1): 1-13.

3. Begley DJ. Understanding and circumventing the blood-brain barrier. Acta Paediatr Suppl. 2003; 92: 83-91.

4. Lefauconneir JM. The blood brain barrier. J Physiological Data. 1998; 140 (1): 3-13.

5. Alyautdin RN, Petrov VE, Kharkevich DA, Kreuter J. Passage of peptides across the blood-brain barrier with nanoparticles. Eur $J$ Pharm Sci. 1994; (3): 91-2.

6. Bibel M, Barde Y. Neurotrophins: key regulator of cell fate and cell shape in the vertebrate nervous system. Genes Dev. 2000; (14): 2919-37.

7. Castellenos-Ortega MR, Cruz-Aguado R, Martinez-Marty L. Nerve growth factor: possibilities and limitations of its clinical application. Rev Neurol. 1999; 29 (5): 439-71.

8. Przedborski S, Jackson-Lewis V, Djaldetti R, Liberatore G, Vila M, Vukosavic S, Almer G. The parkinsonian toxin MPTP: action and mechanism. Restor Neurol Neurosci. 2000; 16 (2): 135-42.

9. Kreuter J. Nanoparticulate systems for brain delivery of drugs Adv Drug Deliv Rev. 2001; (47): 65-81.

10. Kurakhmaeva K, Djindjikhashvili I, Petrov V, Balabanjan V, Voronina T,

\section{Литература}

1. Аляутдин Р. Н., Дешмух Р., Петров В. Е. Транспорт лекарственных веществ через гематоэнцесралический барьер. Вестник НИИ Молекулярной медицины. 2003; 11-29.

2. Lockman PR, Mumper RJ, Khan MA, Allen DD. Nanoparticle technology for drug delivery across blood-brain barrier. Drug Dev Ind Pharm. 2002; 28 (1): 1-13.

3. Begley DJ. Understanding and circumventing the blood-brain barrier. Acta Paediatr Suppl. 2003; (92): 83-91.

4. Lefauconneir JM. The blood brain barrier. J Physiological data. 1998; 140 (1): 3-13.

5. Alyautdin RN, Petrov VE, Kharkevich DA, Kreuter J. Passage of peptides across the blood-brain barrier with nanoparticles. Eur $J$ Pharm Sci. 1994; (3): 91-2.

6. Bibel M, Barde Y. Neurotrophins: key regulator of cell fate and cell shape in the vertebrate nervous system. Genes Dev. 2000; (14): 2919-37.

7. Castellenos-Ortega MR, Cruz-Aguado R, Martinez-Marty L. Nerve growth factor: possibilities and limitations of its clinical application. Rev Neurol. 1999; 29 (5): 439-71.

8. Przedborski S, Jackson-Lewis V, Djaldetti R, Liberatore G, Vila M, Vukosavic S, Almer G. The parkinsonian toxin MPTP: action and mechanism. Restor Neurol Neurosci. 2000; 16 (2): 135-42.

9. Kreuter J. Nanoparticulate systems for brain delivery of drugs. Adv Drug Deliv Rev. 2001; (47): 65-81.

10. Kurakhmaeva K, Djindjikhashvili I, Petrov V, Balabanjan V, Voronina T,
Trofimov $\mathrm{S}$ et al. Brain targeting of nerve growth factor using poly(butylcyanoacrilate) nanoparticles. J Drug Targ. 2009; (17): $564-74$.

11. Limongi T, Rocchi A, Cesca F, Tan H, Miele E, Giugni A. Delivery of Brain-Derived Neurotrophic Factor by 3D Biocompatible Polymeric Scaffolds for Neural Tissue Engineering and Neuronal Regeneration. Mol Neurobiol. 2018 Mar 29. DOI: 10.1007/ s12035-018-1022-z.

12. Tyler WJ, Perrett, Pozzo-Miller LD. The role of neurotrophins in neurotransmitter release. Neuroscience. 2002; (8): 524-31.

13. Schindowski K, Belarbi K, Buée L. Neurotrophic factors in Alzheimer's disease: role of axonal transport. Genes Brain Behav. 2008; (7): 43-56.

14. Bhurtel S, Katila N, Neupane S, Srivastav S, Park PH, Choi D. Methyleneblue protects dopaminergic neurons against MPTPinduced neurotoxicity by upregulating brain-derived neurotrophic factor. Ann N Y Acad Sci. 2018.DOI: 10.1111/nyas.13870. Available at: https://www.ncbi.nlm.nih.gov/pubmed/29882218\#.

15. Chen JF, Wang M, Zhuang YH, Behnisch T. Intracerebroventricularlyadministered 1-methyl-4-phenylpyridinium ion and brain derived neurotrophic factor affect catecholaminergic nerve terminals and neurogenesis in the hippocampus, striatum and substantia nigra. Neural Regen Res. 2018; (13): 717-26. DOI: 10.4103/16735374.230300.

Trofimov $S$ et al. Brain targeting of nerve growth factor using poly(butylcyanoacrilate) nanoparticles. J Drug Targ. 2009; (17): $564-74$.

11. Limongi T, Rocchi A, Cesca F, Tan H, Miele E, Giugni A. Delivery of Brain-Derived Neurotrophic Factor by 3D Biocompatible Polymeric Scaffolds for Neural Tissue Engineering and Neuronal Regeneration. Mol Neurobiol. 2018 Mar 29; DOI: 10.1007/ s12035-018-1022-z.

12. Tyler WJ, Perrett, Pozzo-Miller LD. The role of neurotrophins in neurotransmitter release. Neuroscience. 2002; (8): 524-31.

13. Schindowski K, Belarbi K, Buée L. Neurotrophic factors in Alzheimer's disease: role of axonal transport. Genes Brain Behav. 2008; (7): 43-56.

14. Bhurtel S, Katila N, Neupane S, Srivastav S, Park PH, Choi D. Methyleneblue protects dopaminergic neurons against MPTP-induced neurotoxicity by upregulating brain-derived neurotrophic factor. Ann N Y Acad Sci, 2018. DOI: 10.1111/ nyas.13870. Доступно по ссылке: https://www.ncbi.nlm.nih. gov/pubmed/29882218\#.

15. Chen JF, Wang M, Zhuang YH, Behnisch T. Intracerebroventricularlyadministered 1-methyl-4-phenylpyridinium ion and brain derived neurotrophic factor affect catecholaminergic nerve terminals and neurogenesis in the hippocampus, striatum and substantia nigra. Neural Regen Res. 2018; (13): 717-26. DOI: 10.4103/16735374.230300. 